\author{
Sofiia YANKEVYCH, \\ orcid.org/0000-0002-4460-5103 \\ Postgraduate Student at Department of Theory and History of Arts \\ Kharkiv State Academy of Design and Arts \\ (Kharkiv,Ukraine) sayankevich@gmail.com
}

\title{
GENESIS OF THE AVANT-GARDE ART OF THEATER ARTIST M. KYPRIIAN
}

The article considers the origins of the art of the unrecognized creator of Ukrainian avant-garde scenography Myron Kypriian. The artist worked at the National Drama Theater named after M. Zankovetska) for more than half a century, from the entrance to the Lviv Academy of Arts in 1954 (Institute of Applied and Decorative Arts), and to the end of his life (2020). M. Kypriian's works are presented in the author's albums of the artist and scientific works of art critic $O$. Shpakovych, theatrical publications and reviews of performances. The study of M. Kypriian's artistic practice is still inexhaustible and has prospects not only in the field of theatre studies, but also in the field of art history. The purpose of the article is to determine the origins of M. Kypriian's avant-garde art. The main material of the article is divided into two parts. In the part "Life through the prism of tragedy" the process of formation of M. Kypriian as an artist from the first years of life is investigated. The influence of external factors on the formation of M. Kypriian's artistic thinking and the specifics of his authorial style are conditioned. The basic biographical facts and life moments that influenced the formation of synthetic thinking necessary for a theatrical artist are identified. In the part "Time of the post-war avant-garde" the connection of $M$. Kypriian's stage projects with avant-garde directions in the Ukrainian fine arts is defined. Beginning in the 1960s, the theatrical work of the artist was significantly influenced by Ukrainian scenographers (O. Exter, A. Petritsky, V. Meller, B. Kosarev). Parallels are drawn between painting and theatrical design of the artist. The basic principles of creating decorative sketches by $M$. Kypriian are named: avant-garde solution of decorative projects, compositional structure, use of color and light-shadow accents. The place of M. Kypriian's scenography in the system of theatrical and decorative practice of Ukraine of the XX century is established. The article examines the genesis of the artist's creative search, the influence of wartime on the individual style of his artistic decisions.

Key words: Ukrainian art, scenography, theatrical artist, Ukrainian avant-garde, post-war avant-garde.

Сорія ЯНКЕВИЧ, orcid.org/0000-0002-4460-5103 аспірантка кафедри теорії та історії мистеитва Харківської державної академї̈ дизайну і мистецттв (Харків, Україна) sayankevich@gmail.com

\section{ГЕНЕЗА АВАНГАРДНОГО МИСТЕЦТВА ТЕАТРАЛЬНОГО ХУДОЖНИКА М. КИПРІЯНА}

\begin{abstract}
У статті розглянуто витоки мистецтвва невизнаного твория украӥнського авангардного мистецтва сценографії Мирона Кипріяна. Художник працював у Національному драматичному театрі ім. М. Заньковецької) більше півстоліття, починаючи від вступудоЛьвівськоїакадеміїмистецтву 1954 р. (Інститутприкладного тадекоративного мистецтва), і до кіния свого життя (2020). Творчість М. Кипріяна представлена в авторських альбомах художника та наукових прачях мистецтвознавия О. Шпакович, театрознавчих виданнях та рецензіях на вистави. Дослідження мистецької практики М. Кипріяна досі не вичерпане та має перспективи не лише в галузі театрознавства, а й на ниві мистецтвознавства. Мета статті - визначити витоки авангардного мистецтва М. Кипріяна. Виклад основного матеріалу статті розділено на два параграфи. У параграфі «Життя крізь призму трагедї» досліджено процес формування М. Кипріяна як митџя з перших років життя. Зумовлено вплив зовнішніх чинників на формування художнього мислення М. Кипріяна і специфікуйого авторського стилю. Зазначені основні біографічні факти іжиттєві моменти, щзо вплинули на утворення синтетичного мислення, необхідного для театрального художника. У параграфі «Час післявоєнного авангарду» визначено зв'язок сиенічних проєктів М. Кипріяна з авангардними напрямами в українському образотворчому мистецтвві. Починаючи від 1960-х років театральна творчість художника знаходилася під помітним впливом украӥнських сценографів (О. Екстер, А. Петрищький, В. Меллер, Б. Косарєв). Проведено паралелі між живописом та театральним дизайном художника. Названі базові принципи створення декораційних ескізів М. Кипріяна: авангардне вирішення декорачійних проєктів, композиџійна будова, використання кольору та світо-тіньових акиентів. Встановлено місие сценографії М. Кипріяна в системі театрально-декораційної практики України ХХ століття. У статті досліджено генезис творчих пошуків мития, вплив воєнного часу на індивідуальний стиль його образотворчих рішень, тандем художника з режисером-постановником.
\end{abstract}

Ключові слова: украӥнське мистечтво, сценографія, театральний художник, український авангард, післявоєнний авангард. 
Formulation of the problem. Not every artist draws attention to his work. Myron Kypriian, a Ukrainian painter and theatrical decorator from the western lands of Ukraine, became an iconic figure in the Ukrainian art of the 20th century. In 2019, at the age of 89, the artist passed away, leaving behind a significant artistic legacy and a train of memories of his contemporaries about joint creative achievements. M. Kypriian should be considered a true man of the theatre, an unrecognized creator of Ukrainian avant-garde scenography, which is important for the approval of the actualization of our study. The end of the life and creative path of an outstanding individual, as well as the end of any era, is accompanied by the logic of the need to summarize. We have the task to establish the name of M. Kypriian as the original scenographer of the 20th century with a solid foundation for the avant-garde art he created.

Research analysis. The artist made a lot of efforts for the population of his own creative work: he organized a theater museum; published memoirs and albums about his achievements and the history of the family (Kypriian, 2007, 2011, 2015); provided original sketches to the collections of Ukrainian museums. Despite his significant contribution to Ukrainian art, M. Kypriian's work has not been studied much.

Currently, a young Lviv scientist O. Shpakovych is conducting a comprehensive research within the dissertation of art history work on the work of M. Kypriian. Today, her texts have been tested in several Ukrainian magazines and conferences ("Theatrical costume in the works of Myron Kypriian", 2018; "What did Myron Kypriian leave us?", 2019; "Myron Kyprian's first performances at the Maria Zankovetska Theater in the late 50's - early 60's of the 20th century", 2020; "The stage design by Myron Kypriian in 60's of the 20th century", 2020). The art critic provides historical information about the life and formation of M. Kypriian as an artist; tells about the specifics of his creation of theatrical scenery, as well as theatrical costume; quotes from Lviv journalism, archival documents, private interviews with the artist and his professional environment; popularizes museum and private photographs and sketches to M. Kypriian's art projects. O. Shpakovych appeals to the terms "synthetic art", "dynamic image", "effective scenography", "costume design", affirming the name of M. Kypriian in the annals of modern art science. Some interest of researchers in the work of the artist comes from theater historians and practitioners. M. Kyprian's stage works are inscribed in the context of the theatrical heritage of Ukraine as a part of the monograph (Sidorenko, 2006), scientific collection, theatrical review (Shchukina, 2020), articles (Har- buziuk, 1994: 28-32), comparative element in the dissertation (Klimko, 2014: 189-201).

The purpose of the article - investigate the origins of M. Kypriian's avant-garde art and artistic connections with artists of Ukrainian post-war avantgarde art.

Presenting main material. Part 1. Life through the prism of tragedy. Avant-garde artistic solutions appeared in the works of M. Kypriian from the 1960s and continued their progression and reflection until the last years of his life. And this leads to the fairness of the idea that every production, every artistic decision has its time. That the conditions in which the creative process takes place dictate the artist's motivation, explain his final work. It is appropriate to talk about the uniqueness of art, if it is not a copy of everyday life, devoid of creative desire. According to the dictionary, art is "one of the forms of social consciousness that reflects the real reality in images and participates in its historical development" (Sotskaya: 11). The obvious motivation of M. Kypriian's art is his own unpleasant experience, which directly affected the artist's artistic handwriting.

M. Kypriian's childhood was nurtured by art. The artist spent the first years of his life in the town of Vynnyky, Lviv region. He lost his father at the age of four. Volodymyr Kypriian was a legionnaire of the Ukrainian Sich Riflemen, the founder of the philatelic movement in Galicia. His death in 1934 laid the foundation for the tragic worldview of the future artist. The son did not know the father's love at a conscious age, did not receive a male upbringing. However, the immense war for the little boy hardened his forehead. World War II fell on the childhood of M. Kypriian, forming a true idea of the artist about what is a tragedy. During war there is always a destruction of human consciousness. It has the greatest impact on the common sense of the younger generation, which very quickly absorbs the harshness of life. War is always a conversation about power and obedience, collective consciousness and the suppression of individuality. World discord is a familiar plot in the cyclical history of human existence. At least once a century, the beastly beginning, as scheduled, embraces humanity; and in the brutality of war something bright and cheerful is born: faith in the best, faith in art. However, this art, although beautiful, has a bitter taste. M. Kypriian described his childhood memories and adventures in his memoirs, as well as in interviews: "During the war, as children, we staged performances in the yard, made decorations, changed clothes" (Maksimenko, 2013: 12). For the artist, the art of theater became the axis that gave hope and happiness: "It was like a break between life and death. 
Because you never knew if you would be gone in five minutes. It is a nirvana between life and death, which kept us all alive, with desire, with those high human values that must be carried to the end of our age" (Maksimenko, 2013: 13). M. Kypriian and his childhood friend performed plays on the streets of Vynnyky right under the noise of explosions and in constant readiness for death. Memorable moments from the childhood of M. Kypriian, which the artist mentions in his memoirs, formed the basis of his decorative decisions for the performances: "Ladies and Hussars" by O. Fredro, "People's Malachi" by M. Kulish, "The Last Stop" by Je. Remarque.

History knows many talented people who grew and developed in the artistic circle. Strong artistic ties formed M. Kypriian as a multifaceted personality. Throughout his life, the set designer actively researched the family tree, describing the intricacies of the ties of famous relatives and acquaintances in his own memoirs. The artist especially emphasizes the involvement of a kind in various fields of art. His mother studied at the Academy of Arts in Krakow, but did not complete her education due to the 1914 war. Her favorite paintings were the most famous paintings of Renaissance artists Leonardo da Vinci's "Mona Lisa" and Raphael Santi's "Madonna in a Chair", reproductions of which hung in the house like life-saving icons. The upbringing of his mother and grandmother prompted M. Kypriian to develop a fine aesthetic taste, even in difficult times. "The world of theater, its "meaning" and its appeal have been known to me since childhood because my mother's friends were actors of various theatrical traveling troupes at the time: Olena Benzal-Karpyak, Yosyf Hirnyak, Volodymyr Blavatsky, Ida Kaminska, Lesya Kryvytska, Yosyf Stadnyk, Stefa Stadnykivna" (Kypriian, 2007: 88), - the artist recalled. M Kypriian also became acquainted with drama as a basis for stage action at an early age. After all, during the war, traveling troupes, passing through Vynnyky, left the artist's family their plays and directorial texts.

After the war, the artist did not intend to link his professional activities with theatrical work, but fate guided his intentions. The artist's artistic path was through learning music: singing, playing the piano; choreography; painting. Namely, the theater became a springboard for the realization of synthetic artistic thinking of M. Kypriian. In 1947, M. Kypriian entered the Lviv Academy of Arts, the official opening of which took place in 1946. Vitold Monastyrsky, a teacher of the Department of Drawing (son of the artist Anton Monastyrsky, studied at the Warsaw Academy of Arts), became a teacher of the artistic language of painting for M. Kypri- ian. V. Monastyrsky was a master of domestic painting, portrait, landscape, still life. In the introductory article to the album of works of the artist in 1977 it is noted that his work "glorifies the beauty of the native renewed Carpathians" and "images of contemporaries" (Monastyrsky, 1977). M. Kypriian's art was significantly influenced by V. Monastyrsky's art school. Starting from the genres of painting (portrait, landscape, still life), in which the theatrical artist worked all his life, ending with borrowing the style of writing of the Post-Impressionists (which V. Monastyrsky himself learned while in Krakow). Quite quickly M. Kypriian moved from the field of painting to theatrical practice. In 1949, while still a student at the academy, the young artist began painting scenery at the Lviv Opera House. It would seem that he is a young man with little experience, or even still studying painting, and he has already been invited to lead the studio of fine arts at the Teacher's House, and in 1954 - as a decorator for the puppet theatre.

In 1957, M. Kypriian was offered the position of production designer, and in 1963 - the main artist in the Theatre named after M. Zankovetska. Thus, the painter, without special theatrical training, but with a powerful school of life, connected his professional activity with the stage.

Today M. Kypriian can be considered a unique professional theatre artist of Ukraine without a scenographic school. "He is his own school. His talent, intelligence, ability to work were enough to be a KYPRIIAN" (Khudytsky, 2010), - so aptly said the director V. Sikorsky, with whom the artist has repeatedly collaborated. Understanding of theatrical specifics came to the artist in an intuitive way: through his curiosity, openness to art, company temperament. M. Kyprian created plays with a large number of directors, many of whom created relevant, intelligent Ukrainian theater: B. Tiahno, O. Barsegyan, M. Gilyarovsky, S. Danchenko, F. Stryhun. In his first work in the theater, the artist performed written scenery on the projects of famous set designers Fedor Nirod and Alexander Salman. And in the drama Theater named after M. Zankovetska observed the work of artist Yuri Stefanchuk.

The specificity of F. Nirod's scenography was the creation of projects for opera and ballet productions. It is his version of the stage design of the ballet "Romeo and Juliet" (premiere in 1971) preserved in the repertoire of the National Opera of Ukraine in Kiev (by UNESCO, the play was recognized as the best interpretation of this work by Shakespeare). Perhaps the understanding of the importance of scale and monumentality in theatrical art originated 
in M. Kypriian at the stage of cooperation with the experienced master F. Nirod.

M. Kypriian took part in the preparation of the first Western Ukrainian "Hamlet" in the drama theatre (1957, directed by B. Tiahno), developing costumes that continued the aesthetics of the decorative design of the previous set designer of the theatre (Yu. Stefanchuk). Both the director and the set designer came from the theatre workshop of the Berezil Art Association, so they possessed the ideological heritage of L. Kurbas and could push M. Kypriian to search for his own plastic metaphor.

When M. Kypriian was asked if he imitated someone in his art, the artist replied: "Did Mozart or Wagner imitate someone? Each person, if he is an individual, does not imitate anyone" (Khudytsky, 2010). The set designer always looked for his own way in art, had a desire to do a good deed and always be only himself. In an interview with theatrical critic M. Harbuziuk, M. Kypriian spoke openly about the state of modern scenography: "And when today we see a sharp decline in professional skills, when the scenography is replaced by secondary quality with Broadway-type design, it becomes painfully sad" (Гарбузюк, 1994: 28). Since the year of the interview (1994), almost nothing has changed in the Ukrainian art of stage design. Even the theatrical idols of the past: "After all, blind epigony is no better, "like" a fascination with Kurbas. It is clear that if Kurbas lived today, he would work in a different way. In what exactly - no one knows. Everyone still has to go their own way. This is the only way" (Harbuziuk, 1994: 28).

Part 2. The time of the postwar avant-garde. Ukrainian art of the second half of the 20th century developed in parallel with European and American, renewing and enriching the traditions of the historical avant-garde of the early twentieth century. Peculiarities of the formation of the Ukrainian post-war avantgarde are inextricably linked with the scenographic activity of M. Kypriian.

The Ukrainian art of the "sixties", to which M. Kypriian belonged, "broke" all patterns of socialist-realist reality. Creators of a worldview renewed by the war, as well as artists whose young temperament did not accept continuous prohibitions not only social, ethical, but also aesthetic, appeared on the artistic horizon. The avant-garde work of painters, graphic artists, and sculptors at the official level was almost completely suppressed and belonged to the category of underground art, a kind of secret elite society of like-minded people from all over modern Ukraine.

Artists close to M. Kypriian were G. Gavrilenko, V. Lamakh, V. Barsky, F. Yuriev, O. Dubovyk, mem- bers of the Club of Creative Youth "Contemporary" (1959-1964): Alla Gorskaya, Galina Sevruk, L. Panchenko. In the west of Ukraine there was an ethnographic direction of fine arts. The Transcarpathian and Lviv (M. Kypriian belonged to it) schools of painting became artistic centers. Emphasis on nationality, ethnicity, life became the basis of the works of F. Minayl, A. Kotska, R. Selsky, K. Zvirynsky. For M. Kypriian's art, love for the native land was a characteristic, even integral component. The artist was personally acquainted with S. Parajanov, who glorified the beauty of Ukrainian Transcarpathian nature, life and customs at the level of cinematography ("Shadows of Forgotten Ancestors", 1964). M. Kypriian used his abilities in depicting the Ukrainian color in the design of productions based on national classics ("Haidamaki", T. Shevchenko, 1963; "Vanity", I. Karpenko-Kary, 1967; "Oh, don't go, Hrytsia, and party", M. Starytsky, 1986). "Ukrainian classics, on which a huge layer of clutches and "authoritative recommendations" lies, which at various stages made it "peasant", "domestic". "Troubled", in the works of M. Kypriian acquires the features of intelligence and poeticism inherent in Ukrainian poetry" (Harbuziuk, 1994: 30), - says actress L. Borovska.

It can be noted that M. Kypriian was "lucky" with the chosen profession of theatrical artist, because the performing arts in the thaw could afford more expression of will than the fine arts. "The Ukrainian scene became a realm where the harsh socialist-realist doctrine often receded under the influence of drama, directing and artistic vision" (Sklyarenko, 2016: 8), says researcher G. Sklyarenko. In the 1960s, artists of the Ukrainian classical avant-garde continued to work: A. Petritsky, V. Yermilov. And although their avant-garde shifts at the beginning of the century were strongly suppressed, the artists did not lose their creative inspiration and were a living proof of the existence of Ukrainian avant-garde art before the war and revolutions.

The genesis of M. Kypriian's art is obvious - the discovery of the plastic avant-garde of the 1910s and especially of the 1920 s with their aesthetic dominant - the constructivist trend. The artist was noticeably influenced by Ukrainian scenographers, who determined the formation of the school by their art - O. Exter, A. Petritsky, V. Meller. In analyzing the theatrical works of M. Kypriian, researchers have repeatedly drawn attention to the constructivist direction of the visual expression of ideas in the sketches of the artist. For the most part, we consider several performances that once gained the most notoriety, such as "Faust and Death" in 1960 by O. Levada (Shpakovych, 2020: 237) and "Haidamaki" in 1963 
after T. Shevchenko (Harbuziuk, 1994: 28; Sklyarenko, 2006). In the work on the play "Faust and Death" was a cosmic fantasy of the artist, ahead of time. M. Kypriian's art, as it was with fiction and cinema (for example, the appearance of modern gadgets - a clamshell phone, tablet, Bluetooth headset, video calls - in the series of the 1960s "Star Trek"), revealed the secrets of the future, answering the question: how a person travels in outer space - before society learned about it. Of course, such a phenomenon could not escape the attention of researchers and became a "magical" component in the creative biography of M. Kypriian. The cosmic theme allowed the artist to justifiably move from the category of realistic to abstract dimension. Thus, various geometric planes appeared in the sketches of the play, arranged in the air space of the sheet in a spiral pattern. The stage substantiation of the abstraction created by the artist is achieved by the presence in the picture of the figure of the character from the play, which immediately outlines the scheme of the mise-en-scène of the production. In this work, the artist's flair was shown not only for the constructivist stage organization, but also for the creation of a full-fledged, picturesquely finished sketch, which can be perceived as an independent work of art.

The conditional solution of M. Kypriian's stage space, in addition to constructivism, appeals to such directions of fine arts as cubism and suprematism. Sketches of the artist of the 1960s for performances of plays by Russian playwrights ("Meetings", unrealized production; "Everything remains for people", S. Alyoshin; "How are you, boy?", V. Panova; "So we will win", M. Shatrov) can be attributed to one cycle with common stylistic devices: the use of screens and prisms (on the principle of "tragic geometry" by G. Craig).

Researchers have determined that the vast majority of M. Kypriian's sketches are made of gouache on paper or cardboard (Shpakovych, 2018). Drawings made of gouache paints are traditionally referred to as a graphic art form. However, M. Kypriian's stage projects are full of picturesque forms of representation of objects: pasty brushstroke, play with tonal gradation of color, selected color scheme and composition. Most of the artist's decorative sketches are similar to the avant-garde works of an easel painter, while the sketches of the costumes are characterized by frank graphic incompleteness, the use of an accented line, inattention to the human figure (the main thing in the sketch is the costume itself). For M. Kypriian, the final version of the sketch project is important, because it is an indicator of the work of a theatrical artist, his personal contribution to the collective work, which completes a certain stage of the release of a new play. M. Kypriian was actively engaged in easel painting: he painted portraits of family members, acquaintances, cultural figures; created still lifes and landscapes. They are characterized by a combination of impressionism of the art form with the naturalism of the image. The background of painting, especially portrait, is full of impression and sometimes even expression of strokes. M. Kypriian's conceptual, avant-garde works are mostly connected with the theater. However, among the artist's creative albums published there are several easel avant-garde works, which can be divided into categories: still life, abstraction, portrait. Still lifes with flowers are made in the form of a geometrized plant composition with a tangible influence of the art of Cubism. The geometric abstraction "Se La Vi" is made in cold colors with tonal gradation of their shades: objects of irregular geometric shape are superimposed on each other in the form of a bizarre composition, where, if desired, you can see the profile of a person. The portrait of an unknown girl called "Red Poppy" (1958) is characterized by the full expression of strokes and colors: pink and black. But the graphic portrait of the composer, conductor Yaroslav Barnych, full of avant-garde representation and immediacy of children's drawing, has a connection with the theatrical practice of M. Kypriian.

Ya. Barnych is considered to be the founder of modern Ukrainian operetta, who wrote four outstanding works for Ukrainian culture. Two of them, "Sharika" and "Hutselka Ksenia" were staged at the Lviv Theatre named after M. Zankovetska in 1995 and 1997 by the joint work of director F. Stryhun and artist M. Kypriian. The play "Sharika" is in the current repertoire of theatre, and photos to it can be seen on the official website of the theatre. The stage space is romanticized by an antique colonnade and flowers hanging in the air. The symbolic element of the design is a huge window inscribed in an ellipse - a hyperbolized by the artist hole to the romantic world of the heroes. The shape of the window resembles a mirror, which is also a symbol of reflection of the feelings and emotions of the audience in the theatre. The "eloquent" frame of the window sparkles with gilding and delicate curves of floral ornament. An optimistic fairy tale created by M. Kypriian emerges from the darkness of the stage. The sketch of the artist's scenery has a clear geometric design. The stage is depicted in fiery colours using the artist's typical theatrical colour stretching. The backdrop of the stage is emphatically romantic, on it gloomy colours from grey to black, made by casual wide strokes, depict waves. 
The sketch for the play "Hutsulka Ksenia" is distinguished by a combination of geometric and antifigurative abstraction. The artist paints a gloomy and mystical background, the form of which borders on surrealism and expression. While the construction of the scene is depicted as a clear geometric composition of concentrated circles and associated geometrically irregular elements. In her online review of performances, Kharkiv theatre critic Yu. Shchukina compared M. Kypriian's artistic decision with the avant-garde scenography of the 1920s: "Minimalism and coloristic laconicism prevailed here. Above the whole "universe' the performances starred abstractly marked, illuminated, the Sun and the Moon, and the vertical dynamics of mise-en-scène was given by spectacular combinations of "waves" of stairs (Shchukina, 2020). In the artist's sketch, the stage space looks looped. The perspective of the drawing is seen through the stairs and the human figure drawn by the artist. Stairs are created by combining oblique geometrized planes with horizontal colored patches that move from the background to the foreground. M. Kypriian again introduces the image of the actor-character into the sketch to outline the mise-en-scène drawing of the play: in the centre of the composition, in the background of the drawing there is a small red spot, which sharply contrasts with the dim blue background.

The artist tends to write sketches of theatrical scenery on a dark background. The slate background of M. Kypriian's sketches imitates the dark space of the stage. Thus, in the design of performances, the set designer proposes the use of the principle of "black cabinet", where all the elements of his scenery are emphasized and actively "act". This feature was noted by art critic O. Shpakovych: "He showed his innovative approach primarily in the organization of the portal of the scene, leaving a black background and backstage, thus adding space or, as he explains, adding air to make the environment "alive', "breathable" (Shpakovych, 2020: 91). Black is the dominant colour in the sketches of M. Kypriian. It emphasizes each element of the scenery, as well as makes "glow" other colors in the sketches. This artistic technique allowed M. Kypriian to create light mise-en-scène in his drawings. The artist was a supporter of the use of effective lighting, which brings him to the ranks of progressive theatre artists in Ukraine.

The post-war avant-garde in M. Kypriian's work was not limited to a specific period of time. All the theatrical art of the artist, beginning in the 1960s and until his death, was imbued with avant-garde searches and tragic monumentality.

Thus, the name of M. Kypriian should definitely be put on a par with the famous creators of Ukrainian scenography of the twentieth century: F. Nirod, D. Borovsky, D. Leader, M. Frenkel, O. Burlin.

Conclusions. The genesis of the creative search of the artist M. Kypriian is investigated. It is determined that social factors significantly influenced the artistic activity of M. Kypriian, hardening his psycho-emotional experience to study global topics. It was the harsh military events that shaped the scenographer's desire for art in general and led to tolerance for each art form separately (theatrical syntheticity). Hence the use in the studied performances of visual means of expression, technical capabilities of the theatre, the conditional language of art, the psychological levers of pressure on the audience.

It is determined that the art of M. Kypriian is connected with the achievements of the plastic avantgarde of the 1910s and 1920s with their aesthetic dominant - the constructivist trend. It is established that the artist was in a creative tandem with many directors (M. Gilyarovsky, S. Danchenko, A. Babenko, F. Stryhun), and also acted within the Ukrainian postwar avant-garde art. Nevertheless, his artistic language was not influenced by others and took place as an independent and fundamentally original.

The absence of a scenographic school in M. Kypriian is substantiated (the artist belonged to the Lviv school of painting, which was reflected in his author's style). Parallels are drawn between the artists of the postwar avant-garde and M. Kypriian. The connection of the artist's scenographic practice with folk art and Ukrainian traditions, which are illuminated by M. Kypriian through the prism of avant-garde vision, is established.

\section{BIBLIOGRAPHY}

1. Гарбузюк М., Боровська Л. Мирон Кипріян. Украӥнський театр. 1994. № 2. С. 28-32.

2. Кипріян М. В. Все в минулому. Львів : Панорама, 2007. 300 с.

3. Кипріян М. В. Спогади. Живопис. Сценографія. Львів : ЗУКЦ, 2011. 328 с.

4. Кипріян М. В. Костюм до театральних вистав. Львів : ВД Панорама, 2015. 148 с.

5. Климко 3. В. Виявлення тенденцій і особливих відмінностей в творчій біографії Є. М. Лисика в порівнянні із досягненнями інших майстрів сценографії. Вісник Національного університету «Львівська політехніка». Архітектура. 2014. № 793. С. 189-201.

6. Максименко С. Мирон Кипріян: «Театр - нірвана між життям і смертю...». Кіно-Театр. 2013. № 3. С. 12-13.

7. Монастирський В. Альбом. Художники в Україні. Київ : Мистецтво, 1977. 87 с. 
8. Нариси з історії театрального мистецтва України XX століття / В. Сидоренко (голова) та ін.; Акад. мистецтв України, Ін-т пробл. сучас. мистецтва. Київ : Інтертехнологія, 2006. 1064 с.

9. Скляренко Г. Мистецтво Києва: од відлиги до перебудови. Каталог виставки. Київ : Аукціонний дім «Дукат», 2016. $178 \mathrm{c}$.

10. Сотська Г., Шмельова Т. Словник мистецьких термінів. Інститут педагогічної освіти і освіти дорослих НАПН України. Херсон : Видавничий дім «Стар», 2016. 52 с.

11. Худрицький В. «Художник Мирон Кипіян: останній володар старовинного замку». ZN.UA. 2010. № 28, 6-13 серпня. URL: https://zn.ua/ukr/SOCIUM/hudozhnik_miron_kipriyan_ostanniy_volodar_starodavnogo_zamku.html (дата звернення 22 лютого 2021 р.)

12. Шпакович О. О. Перші вистави Мирона Кипріяна в театрі імені Марії Заньковецької кінця 50-х - початку 60-х років ХХ століття. Традииї та новащії. 2020. № 1. С. 88-95.

13. Шпакович О. О. Сценографічна діяльність М. Кипріяна в 60-х роках XX ст., Народознавчі зошити. 2020. № 1 (151). C. 233-244.

14. Шпакович О. О. Що нам залишив Мирон Кипріян? Образотворче мистецтво. 2019. № 4. С. 120.

15. Шпакович О. Театральний костюм у творчості Мирона Кипріяна. Вісник Львівської національної академії мистейтв. 2018. № 38. С. 208-225.

16. Щукіна Ю. URL: https://www.facebook.com/profile.php?id=100001036983813 (дата звернення 22 лютого 2021 року).

\section{REFERENCES}

1. Harbuziuk M., Borovska L. Myron Kypriian [Myron Kypriian]. Ukrainskyi teatr. 1994. № 2. S. 28-32 [in Ukrainian].

2. Kypriian M. V. Vse v mynulomu [All in the past]. Lviv : Panorama, 2007. 300 s. [in Ukrainian].

3. Kypriian M. V. Spohady. Zhyvopys. Stsenohrafiia [Memories. Painting. Scenography]. L. : ZUKTs, 2011.328 s. [in Ukrainian].

4. Kypriian M. V. Kostium do teatralnykh vystav [Costume for Theatrical Performances]. Lviv : VD Panorama, 2015. 148 s. [in Ukrainian].

5. Klymko Z. V. Vyiavlennia tendentsii i osoblyvykh vidminnostei v tvorchii biohrafii Ye. M. Lysyka v porivnianni iz dosiahnenniamy inshykh maistriv stsenohrafii [Identification of tendencies and special differences in the creative biography of EM Lysyk in comparison with the achievements of other masters of scenography]. Visnyk Natsionalnoho universytetu "Lvivska politekhnika". Arkhitektura. 2014. № 793. S. 189-201 [in Ukrainian].

6. Maksymenko S. Myron Kypriian: «Teatr - nirvana mizh zhyttiam i smertiu...» [Theatre - Nirvana between Life and Death]. Kino-Teatr. 2013. № 3. S. 12-13 [in Ukrainian].

7. Monastyrskyi V. Albom. Khudozhnyky v Ukraini [Artists in Ukraine], Kyiv: Mystetstvo, 1977. 87 s. [in Ukrainian].

8. Narysy z istorii teatralnoho mystetstva Ukrainy XX stolittia [Essays on the history of theatrical art of Ukraine of the twentieth century] / V. Sydorenko (holova) ta in.; Akad. mystetstv Ukrainy, In-t probl. suchas. mystetstva. Kyiv : Intertekhnolohiia, 2006. 1064 s. [in Ukrainian].

9. Skliarenko H. Mystetstvo Kyieva: od vidlyhy do perebudovy [Kyiv's art from thaw to perestroika]. Kataloh vystavky. Kyiv: Auktsionnyi dim «Dukat», 2016. 178 s. [in Ukrainian].

10. Sotska H., Shmelova T. Slovnyk mystetskykh terminiv [Dictionary of artistic terms]. Instytut pedahohichnoi osvity i osvity doroslykh NAPN Ukrainy. Kherson: Vydavnychyi dim «Star», 2016. 52 s. [in Ukrainian].

11. Khudrytskyi V. Khudozhnyk Myron Kypiian: ostannii volodar starovynnoho zamku [Artist Myron Kypriian: the last owner of the ancient castle]. ZN.UA. № 28, 6-13 serpnia, 2010. URL: https://zn.ua/ukr/SOCIUM/hudozhnik_miron_kipriyan_ostanniy_volodar_starodavnogo_zamku.html [dostup 22 liutoho 2021]

12. Shpakovych O. O. Pershi vystavy Myrona Kypriiana v teatri imeni Marii Zankovetskoi kintsia 50-kh - pochatku 60-kh rokiv KhKh stolittia [Myron Kyprian's first performances at the Maria Zankovetska Theater in the late 1950s and early 1960s]. Tradytsii ta novatsii, № 1, 2020, 88-95. [in Ukrainian].

13. Shpakovych O. O. Stsenohrafichna diialnist M. Kypriiana v 60-kh rokakh KhKh st. [The stage design by Myron Kyprian in 60s of the 20th century], Narodoznavchi zoshyty, № 1 (151), 2020. 233-244. [in Ukrainian].

14. Shpakovych O. O. Shcho nam zalyshyv Myron Kypriian? [What did Myron Kyprian leave us?]. Obrazotvorche mystetstvo. 2019. № 4. S. 120. [in Ukrainian].

15. Shpakovych O. Teatralnyi kostium u tvorchosti Myrona Kypriiana [Theatrical costume by Myron Kyprian]. Visnyk Lvivskoi natsionalnoi akademii mystetstv. 2018. № 38. S. 208-225. [in Ukrainian].

16. Shchukina Yu. URL: https://www.facebook.com/profile.php?id=100001036983813 [dostup 22 liutoho 2021] [in Ukrainian]. 